\title{
THE EFFECT OF AMINO ACID L-ALPHA PROLINE AND NITROGEN BACTERIA AZOTOBACTER VINELANDII ON THE CONTENT OF MICROELEMENTS AGAINST THE BACKGROUND OF MINERAL NITROGEN FERTILIZATION
}

\author{
PŁAZA, A. ${ }^{*}-$ RZĄŻEWSKA, E. \\ Siedlce University of Natural Sciences and Humanities, Faculty of Agrobioengineering and \\ Animal Husbandry, Siedlce, Poland \\ ${ }^{*}$ Corresponding author \\ e-mail: anna.plaza@uph.edu.pl \\ (Received 31 $1^{\text {st }}$ May 2021; accepted $3^{\text {rd }}$ Sep 2021)
}

\begin{abstract}
The aim of the research was to determine the effect of L-alpha prolina and Azotoba vinelandii against the background of mineral nitrogen fertilization on the content of microelements in spring wheat grain. Field research work was conducted on a family-owned farm located in Krzymosze. The following two factors were examined: I biological preparations: control where no biological preparations were applied, L-alpha prolina, Azotoba vinelandii, L-alpha prolina+Azotobacter vinelandii; II mineral nitrogen fertiliser regime: non-fertilised control, $60 \mathrm{~kg} \mathrm{~N} \mathrm{Nh}^{-1}, 90 \mathrm{~kg} \mathrm{Nha}^{-1}, 120 \mathrm{~kg} \mathrm{Nha}^{-1}$. Spring wheat grain was sampled to determine microelements. The obtained results revealed that the application of biofertilizers increased iron and zinc contents but reduced manganese and copper concentrations in spring wheat grain. The highest content of iron and zinc, and the lowest concentration of manganese and copper were recorded in spring wheat grain after application of $\mathrm{L}$-alpha prolina + Azotoba vinelandii biological preparations with a dose of mineral nitrogen fertilization of $90 \mathrm{~kg} \mathrm{~N} \mathrm{ha}^{-1}$.
\end{abstract}

Keywords: nitrogen bacteria, mineral content, grain, fertilization, biostimulator

\section{Introduction}

Due to the occurrence of years with a shortage of precipitation and high temperature in Poland, cereal crops do not yield consistently and bring lower yields than expected. Thus, climate warming poses threats to arable crops (Radkowski and Radkowska, 2013; Colla et al., 2014; Du Jardin, 2015). To combat this adverse climate change, biological methods must be used in developing a system of sustainable agriculture. One of the ways is the use of biostimulants, which have a positive effect on the growth and development of plants and have a protective function for cells, which makes plants resistant to rainfall deficiency during the growing season (Michalak and Chojnacka, 2013; Calvo et al., 2014; Du Jardin, 2015). A good biological substance may be the amino acid L-alpha proline, which is easily absorbed by plants. Proline is the most widely distributed metabolite that accumulates under stress conditions (Delauney and Verma, 1993) the significance of this accumulation in osmotic adjustment in plants is still debated and varies from species to species (Hoai et al., 2003). According to Qotob et al. (2019) data obtained could be concluded that the using of plant growth regulators as a proline reduced the consumption of mineral fertilizers. There are no studies determining the effect of this amino acid on the chemical composition of grain for consumption. Moreover, in sustainable agriculture it is recommended to limit the use of mineral nitrogen fertilization, in favor of biological nitrogen. The use of nitrogen bacteria is not only a source of nitrogen for plants, but also improves the chemical, biological and physical properties of the soil. This enables plants to take up other nutrients, including micronutrients, which are so important in the human 
diet, especially when used together with biostimulants (Calvo et al., 2014; Muhammed et al., 2016). Bacteria stimulate the growth of the root system, which improves the plant's water and nutrient management. The climate changes that have been noticeable over the last few years, resulting in seasonal droughts, require the intensification of the search for new, but at the same time cheap and pro-environmental solutions, leading to an increase in the use of water by crops. A new solution is the use of bacterial preparations. These goals can be implemented within the framework of the European Green Deal, which assumes the protection of the soil environment by 2030, e.g. by limiting mineral nitrogen fertilization by $20 \%$. Taking into account the advantages of using biological preparations in plant cultivation, research was undertaken to determine the effect of the amino acid L-alpha proline and nitrogen bacteria Azotobacter vinelandii on the background of mineral nitrogen fertilization on the content of microelements in the grain of spring wheat grown in changing weather conditions.

\section{Materials and Methods}

A field experiment was conducted in 2017-2019 on a family owned farm located in

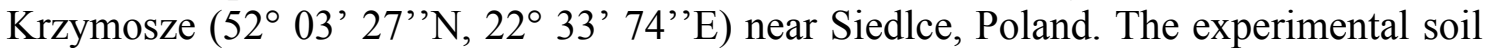
was Stagnic Luvisol (soil classification according to WRB). Available macroelement

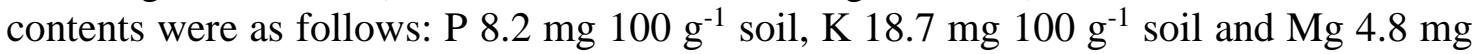
$100 \mathrm{~g}^{-1}$ soil. Microelement contents amounted to: $\mathrm{Mn} 131 \mathrm{mg} \mathrm{kg}^{-1}$ soil, $\mathrm{Cu} 4.9 \mathrm{mg}^{\circ} \mathrm{kg}^{-1}$ soil, $\mathrm{Zn} 5.5 \mathrm{mg} \mathrm{kg}^{-1}$ soil and Fe $845 \mathrm{mg}^{-1}$ soil. The mineral nitrogen contents were $\mathrm{N}-\mathrm{NH}_{4}+4.97 \mathrm{mgkg}^{-1}$ of soil and $\mathrm{N}^{-N_{3}}{ }_{3} 78.4 \mathrm{mg} \mathrm{kg}^{-1}$ of soil. Soil reaction was neutral and humus content was $1.88 \%$. Chemical analyzes of the soil were performed at the Chemical and Agricultural Station in Warsaw. The experiment was set up with three replicates. The size of the plot for the collection was $16 \mathrm{~m}^{2}$. Spring wheat was sown at a row spacing of $11 \mathrm{~cm}$. The following two factors were examined: (I) biological preparations: control where no biological preparations were applied, L-alpha prolina 2 $\mathrm{g}^{-1}$, Azotoba vinelandii $11 \mathrm{hha}^{-1}$, L-alpha prolina $2 \mathrm{~g}^{-1}+1$ Azotoba vinelandii; (II) mineral nitrogen application regime: non-fertilised control, $60 \mathrm{~kg} \mathrm{~N}^{-1} \mathrm{ha}^{-1}$ (preplant), 90 $\mathrm{kg} \mathrm{N}^{-1}$ (60 kg Noha ${ }^{-1}$ preplant $+30 \mathrm{~kg} \mathrm{~N}^{-1}$ at the stem elongation stage), $120 \mathrm{~kg}$ $\mathrm{N} \mathrm{ha}^{-1}\left(60 \mathrm{~kg} \mathrm{~N}^{-1}\right.$ preplant $+30 \mathrm{~kg} \mathrm{~N}^{-1} \mathrm{ha}^{-1}$ at the stem elongation stage $+30 \mathrm{~kg} \mathrm{~N}^{-}$ 1 - foliar application of $8 \%$ urea solution applied as the stage of initial ear formation). Spring wheat cv. Mandaryna was preceded by maize. After harvesting the forecrop, prewinter plowing was performed, and spring crops were sown before wheat. Phosphorus and potassium fertiliser rates were chosen based on soil availability and amounted to 30.8 and $99.6 \mathrm{~kg} \mathrm{ha}^{-1}$ of $\mathrm{P}$ and $\mathrm{K}$, respectively. Mineral nitrogen regime was as described for factor II above. Mineral nitrogen fertilization before sowing and in the shooting stage (BBCH 30) was applied in the form of 34\% ammonium nitrate. On the other hand, foliar fertilization with $46 \%$ urea in the form of an $8 \%$ solution in the heading stage (BBCH 50). Spring wheat was sown in early April at the rate of 500 grains per $1 \mathrm{~m}^{2}$. Biofertilizers were applied once at the stage of spring wheat tillering $(\mathrm{BBCH} 20)$. First biological preparation contains the Azotobacter vinelandii MVY-010 (1x10 CFU/l) a biological product intended for increasing nitrogen content in the soil. Contains non-symbiotic, freeliving soil bacterium Azotobacter vinelandii, which effectively assimilates the atmospheric nitrogen and extracts bioactive substances that improve the development of plants, and polysaccharide alginates having influence on the formation of water-resistant units in the soil. Second biological preparation contains the L- $\alpha$ proline (purity, $5 \%$ ) a 
biostimulator increasing the natural resistance of plants to the stress. It contains L- $\alpha$ proline 5 (amino acid) easily assimilated by plants that has a multiple effect on the growth and development of plants and performs a protective function of cells as well as helps to adapt to adverse environmental conditions. L- $\alpha$ proline balances the metabolism processes of vital substances and compensates their shortage. Biological preparations should be dissolved in water and sprayed with $2501 \mathrm{ha}^{-1}$ of water. The distributor of biological preparations in Poland is PHU Biotel Sp. zoo. Dzikowice 87, 67-300 Szprotawa. During the plantation, the herbicide Gold $450 \mathrm{SC}$ at a dose of $1.251 \mathrm{ha}^{-1}$, fungicide (the first treatment Bumper Super $490 \mathrm{EC}$ at the dose of $11 \mathrm{ha}^{-1}$; the second treatment Falcon 460 EC $0.61 \mathrm{ha}^{-1}$ ) and the growth regulator Cerone were used. $480 \mathrm{SL}$ $0.751 \mathrm{ha}^{-1}$. Spring wheat was harvested in early August. During spring wheat harvest, grain was sampled to perform chemical analyses. From each plot after the grain was harvested, a representative sample with a volume of $250 \mathrm{~g}$ was taken. Determinations included selected macroelements ( $\mathrm{Fe}, \mathrm{Zn}, \mathrm{Cu}$ and $\mathrm{Mn}$ ) by means of Inductively Coupled Plasma Optical Emission Spectrometry (ICP-OES). Mn (FAAS), Cu (FAAS), Zn (FAAS) and Fe (FAAS). Then the plant material was taken up in acids in a microwave digestor Milesone Ethos Plus. The content of micronutrients was determined in the mineralisation by emission spectrometry with excitation in inductively coupled plasma and an optical detector (ICP OES), using an emission spectrometer Perkin Elmer Optima 8300. The assay was performed in triplicate. The results for each characteristic were subjected to analysis of variance (ANOVA). Comparison of means for significant sources of variation was achieved by means of Tukey's test at the significance level of $P \leq 0.05$. ANOVA with regression was calculated for mineral nitrogen application and content of micronutrients. Significance was tested using Fisher-Snedecor test at significance level at $\mathrm{P} \leq 0.05$ and $\mathrm{P} \leq 0.01$ (Hill and Lewicki, 2006). All the calculations were performed in STATISTICA ${ }^{\circledR}$, version 12.0 .

\section{Results and Discussion}

In Table 1 described significance of the effects in ANOVA (2017-2019).

Table 1. Significance of the effects in ANOVA, results from 2017-2019 years

\begin{tabular}{c|c|c|c|c}
\hline \multirow{2}{*}{ Source of variability } & \multicolumn{4}{|c}{ Trait -content of: } \\
\cline { 2 - 5 } & Iron & Cooper & Manganese & Zinc \\
\hline Year & $\mathrm{ns}$ & $\mathrm{ns}$ & $\mathrm{ns}$ & $* *$ \\
Biological preparation & $* * *$ & $* * *$ & $* * *$ & $* * *$ \\
Nitrogen application & $* * *$ & $* * *$ & $* * *$ & $* *$ \\
Year*Biological preparation & $\mathrm{ns}$ & $\mathrm{ns}$ & $\mathrm{ns}$ & $\mathrm{ns}$ \\
Year*Nitrogen application & $\mathrm{ns}$ & $\mathrm{ns}$ & $\mathrm{ns}$ & $\mathrm{ns}$ \\
Biological preparation*Nitrogen & $*$ & $* *$ & $\mathrm{~ns}$ & $\mathrm{~ns}$ \\
application & & & $\mathrm{ns}$ & $\mathrm{ns}$ \\
Year*Biological & $\mathrm{ns}$ & $\mathrm{ns}$ & $\mathrm{ns}$ & 5.16 \\
preparation*Nitrogen application & 4.98 & 4.36 & 4.07 & \\
Variability coefficient V\% & & & & \\
\hline
\end{tabular}

ns- non significant, $*$ significant at $\mathrm{p}<0.05$, significant at $\mathrm{p}<0.01$, significant at $\mathrm{p}<0.001$ 
Iron content in spring wheat grain was significantly affected by the experimental factors and their interaction (Table 2).

Table 2. Iron content in spring wheat grain (means across 2017-2019), $\mathrm{mg} \mathrm{kg}^{-1} \mathrm{DM}$

\begin{tabular}{c|c|c|c|c|c}
\hline \multirow{2}{*}{ Biological preparatons (A) } & \multicolumn{4}{|c|}{ Mineral nitrogen fertiliser regime (B), $\mathbf{k g} \mathbf{~ N a} \mathbf{h}^{-1}$} & \multirow{2}{*}{ Means } \\
\cline { 2 - 5 } & Control & 60 & 90 & 120 & \\
\hline Control & $34.23 \mathrm{a}^{*}$ & $37.48 \mathrm{a}$ & $36.21 \mathrm{a}$ & $35.44 \mathrm{a}$ & $35.84 \mathrm{D}$ \\
L-alpha proline & $41.12 \mathrm{~b}$ & $49.44 \mathrm{a}$ & $54.17 \mathrm{a}$ & $51.12 \mathrm{a}$ & $48.96 \mathrm{C}$ \\
Azotoba vinelandii & $55.25 \mathrm{~b}$ & $62.31 \mathrm{a}$ & $68.53 \mathrm{a}$ & $65.43 \mathrm{a}$ & $62.88 \mathrm{~B}$ \\
L-alpha proline + Azotobacter vinelandii & $98.21 \mathrm{c}$ & $109.17 \mathrm{~b}$ & $118.50 \mathrm{a}$ & $112.17 \mathrm{ab}$ & $109.5 \mathrm{~A}$ \\
Means & $57.21 \mathrm{C}$ & $64.60 \mathrm{~B}$ & $69.35 \mathrm{~A}$ & $66.04 \mathrm{AB}$ & - \\
\hline
\end{tabular}

"Values in columns followed by the same small letter and values in rows followed by the same capital letter do not differ significantly at $\mathrm{P}<0.05$

The regression line between fertilization of mineral nitrogen and iron content in grain spring wheat showed that increasing the dose of nitrogen to $90 \mathrm{~kg} \mathrm{ha}^{-1}$ increased the iron content in spring wheat grain. The maximum iron content in spring wheat grain was obtained with the use of mineral nitrogen fertilization in the dose of $99.5 \mathrm{~kg} \mathrm{Nha}^{-1}$ (Figure 1).

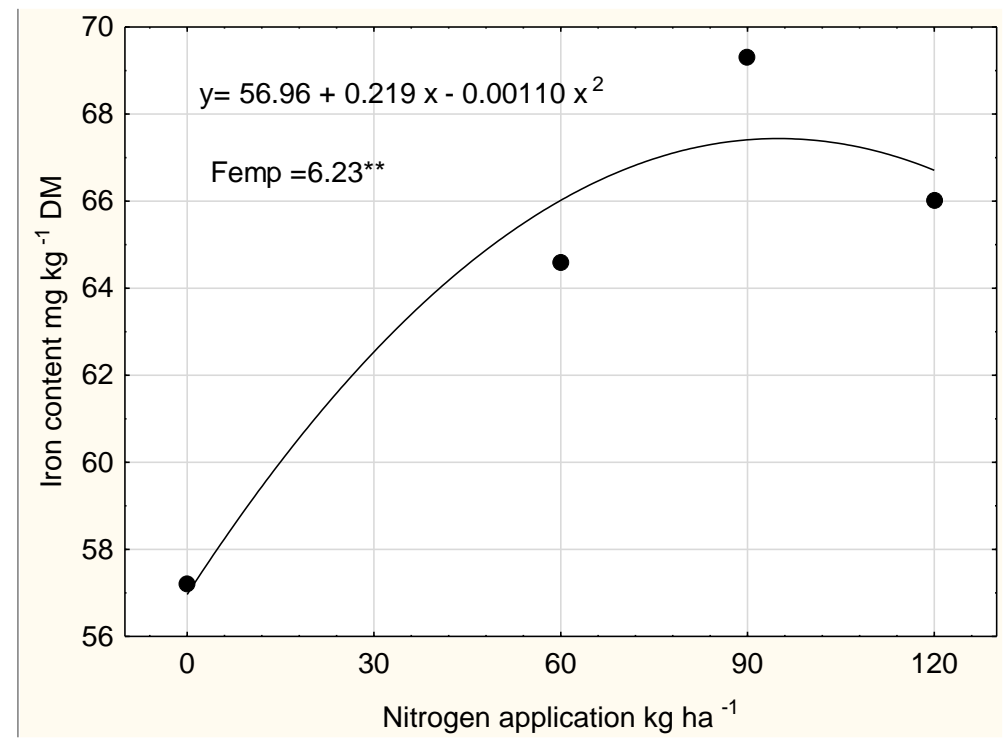

Figure 1. Regression line between ferilization of mineral nitrogen $(x)$ and iron content in grain (y), mean for 2017-2019 years

Iron concentration was the lowest in control spring wheat grain produced with mineral nitrogen input and no biological product application. Also Johansson et al. (2001), Sułek and Cacak-Pietrzak (2008), Gondek and Gondek (2010) as well as Buczek et al. (2011) found the lowest iron content in cereal grain following an application of the highest mineral fertiliser rates. High mineral fertiliser rates, including nitrogen, pose a threat to the natural environment. This leads to pollution of groundwater with nitrates, and 
contributes to poorer crop yield quality due to, among others, less iron which is a valuable microelement (Gondek and Gondek, 2010). In the present study, an application of biofertilizers, in particular Azotoba vinelandii and L-alpha proline + Azotobacter vinelandii, increased iron content in spring wheat grain. L-alpha proline and Azotobacter vinelandiiare microbiological products containing, respectively, the nitrifying bacteria Azotobacter vinelandii, and the essential amino acid L-alpha proline. Mona et al. (2012) have demonstrated that the nitrifying bacteria Azotobacter chroococum and Azospirillum brastlensel contribute to an increase in the wheat grain content of Fe compared with control. A possible explanation is that microorganisms metabolise and then mineralize organic matter, which introduces into circulation the elements which are essential in plant nutrition, including iron which is a microelement so important for human health (Srinivas et al., 2002; Mahamed and Kaharia, 2012). In the experiment reported here, an application of L-alpha proline significantly reduced Fe content in spring wheat grain compared with the bacteria based product. It is due to the fact that bacteria-free L-alpha proline contains only an amino acid which contributes to a lower release of Fe from the soil environment. In the present work, nitrogen fertilisation at lower rates, that is 60 and $90 \mathrm{~kg} \mathrm{~N}^{-1}$, resulted in Fe increase in spring wheat grain compared with control. It was also confirmed that an application of the highest nitrogen rate contributed to a decline in the iron content in spring wheat grain, which was due to the fact that too high nitrogen rates cause soil environment degradation, and reduce microelement uptake by plants. In turn, low mineral nitrogen rates positively affect soil microorganisms which decompose organic matter and release minerals, including iron, for uptake by plants. In the present work, an interaction was confirmed indicating that the highest iron concentration was determined in the grain of spring wheat treated with accompanied by an L-alpha proline + Azotobacter vinelandii application of $90 \mathrm{~kg} \mathrm{~N} \mathrm{ha}^{-1}$. It can be explained by the fact that an application of products containing the bacteria Azotobacter vinelandii, which reduce elemental nitrogen from the air, and the amino acid L-alpha proline, accompanied by nitrogen fertiliser at the rate of $90 \mathrm{~kg} \mathrm{ha}^{-1}$ create favourable conditions for the growth and development of spring wheat, which results in iron accumulation in spring wheat grain. In contrast, an application of the highest nitrogen rate negatively affects the soil environment, similarly to lack of nitrogen fertilisation in the control unit, which resulted in the lowest iron concentration in spring wheat grain.

Statistical analysis demonstrated a significant influence of the experimental factors on manganese content in spring wheat grain (Table 3).

Table 3. Manganese content in spring wheat grain (means across 2017-2019), $\mathrm{mg} \mathrm{kg}^{-1} \mathrm{DM}$

\begin{tabular}{c|c|c|c|c|c}
\hline \multirow{2}{*}{ Biological preparations (A) } & \multicolumn{3}{|c|}{ Mineral nitrogen fertiliser regime (B), kg Noha-1 } & \multirow{2}{*}{ Means } \\
\cline { 2 - 5 } & Control & 60 & 90 & 120 & \\
\hline Control & $74.81 \mathrm{c}$ & $76.23 \mathrm{c}$ & $78.31 \mathrm{c}$ & $84.81 \mathrm{c}$ & $78.54 \mathrm{~A}$ \\
L-alpha proline & $70.12 \mathrm{~b}$ & $73.21 \mathrm{~b}$ & $74.39 \mathrm{~b}$ & $76.20 \mathrm{~b}$ & $73.48 \mathrm{~B}$ \\
Azotoba vinelandii & $68.85 \mathrm{~b}$ & $71.10 \mathrm{~b}$ & $73.14 \mathrm{~b}$ & $77.34 \mathrm{~b}$ & $72.61 \mathrm{~B}$ \\
L-alpha proline + Azotobacter vinelandii & $63.87 \mathrm{a}$ & $65.14 \mathrm{a}$ & $66.38 \mathrm{a}$ & $69.15 \mathrm{a}$ & $66.14 \mathrm{C}$ \\
Means & $69.41 \mathrm{C}$ & $71.42 \mathrm{BC}$ & $73.06 \mathrm{~B}$ & $76.88 \mathrm{~A}$ & - \\
\hline
\end{tabular}

*Values in columns followed by the same small letter and values in rows followed by the same capital letter do not differ significantly at $\mathrm{P}<0.05$ 
The regression line between fertilization of mineral nitrogen and manganese content in grain spring wheat showed that increasing the dose of nitrogen from 60 to $120 \mathrm{~kg} \mathrm{ha}^{-1}$ increased the manganese content in spring wheat grain (Figure 2).

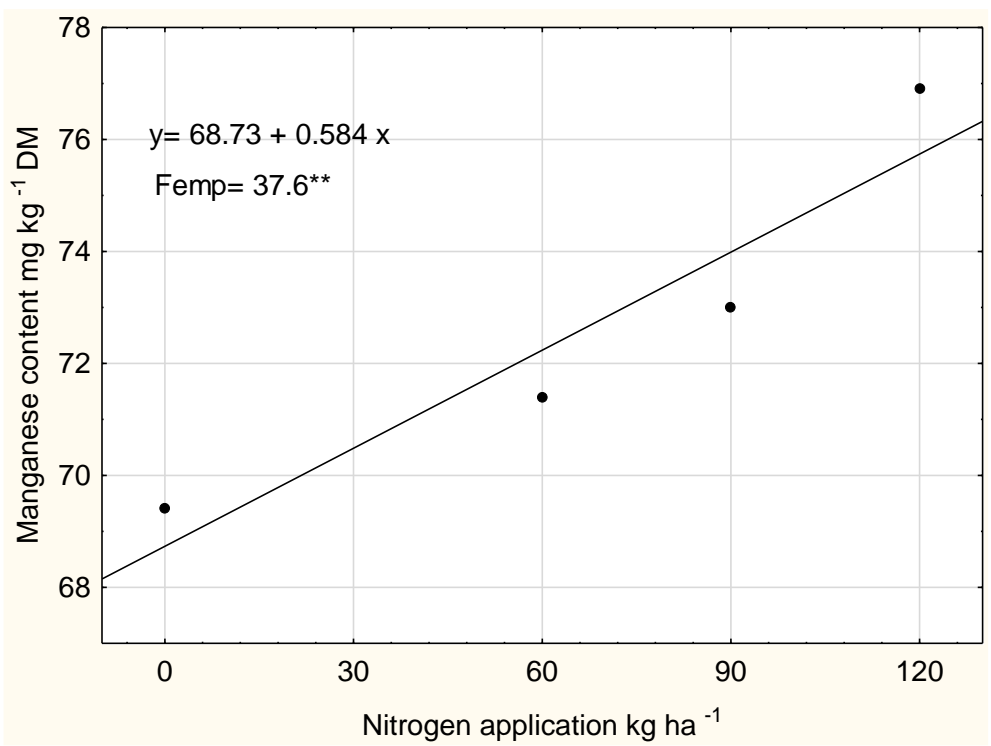

Figure 2. Regression line between ferilization of mineral nitrogen $(x)$ and manganese content in grain (y), mean for 2017-2019 years

The highest concentration of this element was recorded in the grain of spring wheat grown in the control plot where no biofertilizers had been applied. Also research by Johansson et al. (2001), Wang and Malhi (2008) and Jarecki (2019) revealed the highest manganese content in the grain of cereals cultivated using mineral fertiliser input only. In the present study, an application of biofertilizers contributed to a significant decline in Mn concentration in spring wheat grain compared with control. The lowest manganese content was recorded in the grain of spring wheat treated with the two biofertilizers L-alpha proline + Azotobacter vinelandii. It agrees with findings reported by Mona et al. (2012) and Muhammad et al. (2016) who demonstrated that, following an application of nitrifying bacteria, there was observed a decline in the wheat grain content of Mn. It was due to the fact that bacteria have a positive effect on an accumulation of organic matter in which manganese is accumulated. In the experiment reported here, L-alpha proline or Azotobacter vinelandii applied separately increased Mn content in spring wheat grain but its concentration in grain was significantly lower compared with control wheat grain. Nitrogen fertiliser regime significantly affected manganese content in spring wheat grain. An application of increasing nitrogen rates was followed by an increase in the spring wheat grain content of manganese. The highest concentration of this microelement was recorded in the grain of spring wheat fertilised with $120 \mathrm{~kg} \mathrm{~N}^{-1}$. Also Buczek et al. (2011) as well as Jarecki et al. (2019) demonstrated that mineral fertilisation contributed to an increase in the cereal grain content of $\mathrm{Mn}$. A possible explanation is that an application of excessive mineral fertiliser rates leads to soil environment degradation due to reduction in humus which accumulates Mn.

$\mathrm{Zn}$ content in spring wheat grain was significantly affected by the experimental factors (Table 4). 
The regression line between fertilization of mineral nitrogen and zinc content in grain spring wheat showed that increasing the dose of nitrogen to $60 \mathrm{~kg} \mathrm{ha}^{-1}$ increased the zinc content in spring wheat grain. The maximum zinc content in spring wheat grain was obtained with the use of mineral nitrogen fertilization in the dose of $67.59 \mathrm{~kg} \mathrm{Nha}^{-1}$ (Figure 3).

Table 4. Zinc content in spring wheat grain (means across 2017-2019), $\mathrm{mg} \mathrm{kg}^{-1} \mathrm{DM}$

\begin{tabular}{c|c|c|c|c|c}
\hline \multirow{2}{*}{ Biological preparations (A) } & \multicolumn{4}{|c|}{ Mineral nitrogen fertiliser regime (B), $\mathbf{k g} \mathbf{~ N} \mathbf{h a}^{-\mathbf{1}}$} & \multirow{2}{*}{ Means } \\
\cline { 2 - 5 } & Control & 60 & 90 & 120 & \\
\hline Control & $17.94 \mathrm{a}$ & $19.42 \mathrm{a}$ & $18.56 \mathrm{a}$ & $18.14 \mathrm{a}$ & $18.52 \mathrm{D}$ \\
L-alpha proline & $20.37 \mathrm{~b}$ & $23.74 \mathrm{~b}$ & $25.10 \mathrm{~b}$ & $22.75 \mathrm{~b}$ & $22.99 \mathrm{C}$ \\
Azotoba vinelandii & $25.92 \mathrm{c}$ & $27.12 \mathrm{c}$ & $29.31 \mathrm{c}$ & $26.40 \mathrm{c}$ & $27.19 \mathrm{~B}$ \\
L-alpha proline+Azotobacter vinelandii & $28.41 \mathrm{~d}$ & $29.83 \mathrm{~d}$ & $31.47 \mathrm{~d}$ & $29.05 \mathrm{~d}$ & $29.69 \mathrm{~A}$ \\
Means & $23.16 \mathrm{C}$ & $25.03 \mathrm{AB}$ & $26.11 \mathrm{~A}$ & $24.09 \mathrm{BC}$ & - \\
\hline
\end{tabular}

*Values in columns followed by the same small letter and values in rows followed by the same capital letter do not differ significantly at $\mathrm{P}<0.05$

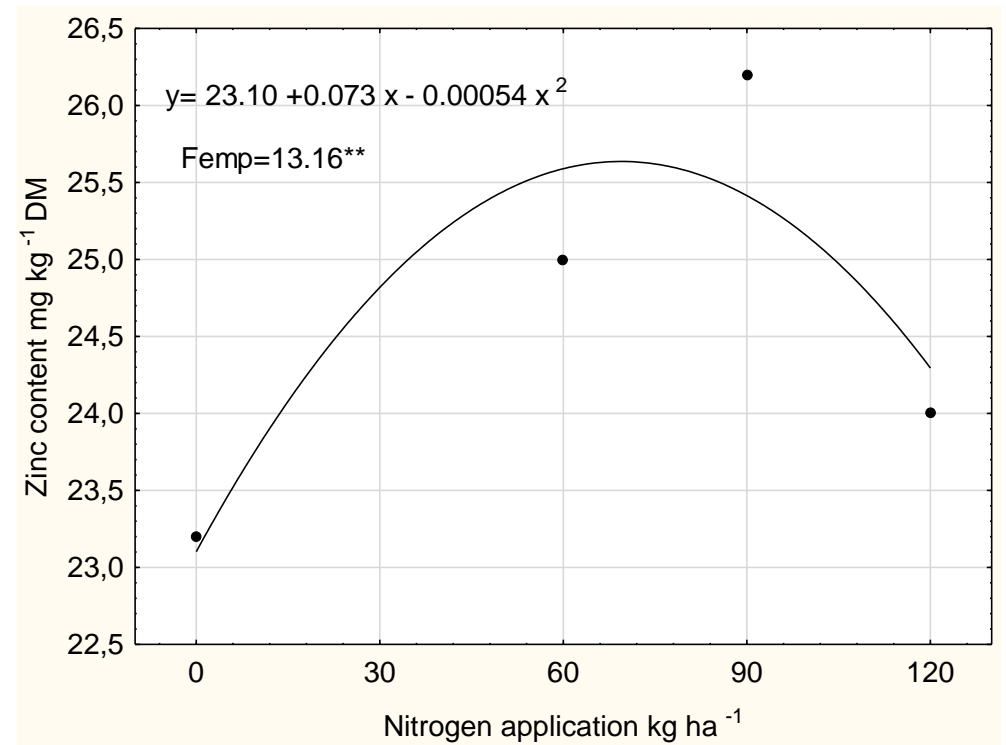

Figure 3. Regression line between fertilization of mineral nitrogen $(x)$ and zinc content in grain (y), mean for 2017-2019 years

Zinc plays an important part in plant metabolism. Both the shortage and excess of this element leads to reduced plant growth and development (Srinivals et al., 2002; Sharma et al., 2004; Luo et al., 2013). In the present work, the lowest zinc content was recorded in control spring wheat grain produced without an application of biological products. By contrast, when applied, the products contributed to an increase in $\mathrm{Zn}$ content in spring wheat grain. The highest concentration of zinc was determined in the grain of spring wheat treated with L-alpha proline + Azotobacter vinelandii. It can be explained by the fact that nitrifying bacteria present in the Azotoba vinelandii positively influence the soil content of organic matter, which after mineralisation releases $\mathrm{Zn}$ as confirmed in the study 
by Mona et al. (2012) whore corded similar relationships following an application of other strains of nitrifying bacteria. In the experiment reported here, nitrogen fertilisation up to the rate of $90 \mathrm{~kg} \mathrm{~N}^{-1}$ increased $\mathrm{Zn}$ concentration in spring wheat grain. However, the highest nitrogen rate was followed by a decline in zinc content in spring wheat grain, which agrees with find in s reported by Sułek and Cacak-Pietrzak (2008) as well as Barczak et al. (2018).

Statistical analysis demonstrated a significant impact of the experimental factors and their interaction on copper content in spring wheat grain (Table 5).

Table 5. Copper content in spring wheat grain (means across 2017-2019), $\mathrm{mg}$ kg-1 DM

\begin{tabular}{c|c|c|ccc|c}
\hline \multirow{2}{*}{ Biological preparations (A) } & \multicolumn{4}{|c|}{ Mineral nitrogen fertiliser regime (B), kg Noha } & \multirow{2}{*}{ Means } \\
\cline { 2 - 5 } & Control & 60 & 90 & 120 & \\
\hline Control & $4.73 \mathrm{c}$ & $5.12 \mathrm{c}$ & $5.79 \mathrm{~b}$ & $6.31 \mathrm{a}$ & $5.49 \mathrm{~A}$ \\
L-alpha proline & $4.32 \mathrm{c}$ & $4.69 \mathrm{bc}$ & $4.83 \mathrm{ab}$ & $5.18 \mathrm{a}$ & $4.76 \mathrm{~B}$ \\
Azotoba vinelandii & $4.11 \mathrm{~b}$ & $4.26 \mathrm{ab}$ & $4.37 \mathrm{ab}$ & $4.59 \mathrm{a}$ & $4.33 \mathrm{C}$ \\
L-alpha proline+Azotobacter vinelandii & $3.84 \mathrm{a}$ & $4.07 \mathrm{a}$ & $4.19 \mathrm{a}$ & $4.31 \mathrm{a}$ & $4.10 \mathrm{C}$ \\
Means & $4.25 \mathrm{D}$ & $4.54 \mathrm{C}$ & $4.80 \mathrm{~B}$ & $5.10 \mathrm{~A}$ & - \\
\hline
\end{tabular}

*Values in columns followed by the same small letter and values in rows followed by the same capital letter do not differ significantly at $\mathrm{P}<0.05$

The regression line between fertilization of mineral nitrogen and cooper content in grain spring wheat showed that increasing the dose of nitrogen from 60 to $120 \mathrm{~kg} \mathrm{ha}^{-1}$ increased the cooper content in spring wheat grain (Figure 4).

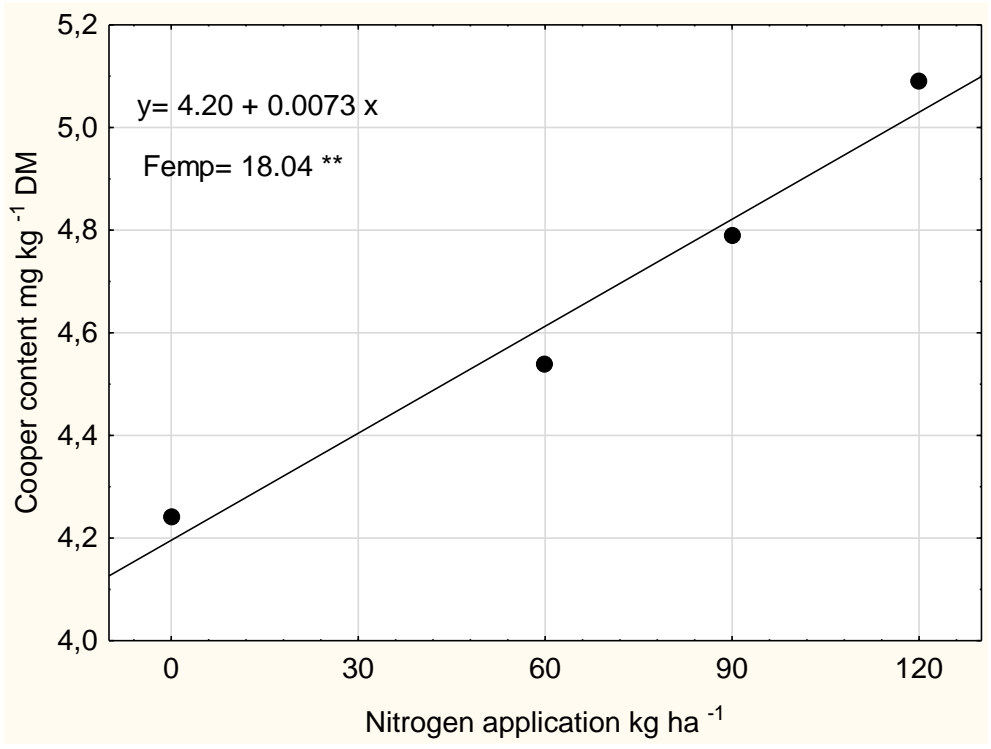

Figure 4. Regression line between ferilization of mineral nitrogen $(x)$ and cooper content in grain (y), mean for 2017-2019 years

The highest copper content was determined in the grain of control spring wheat which had been treated with no biofertilizers. An application of the products, particularly 
Azotoba vinelandii and L-alpha proline + Azotobacter vinelandii, contributed to adecline in copper concentration in spring wheat grain. Bacteria Azotobacter vinelandii which positively affect an accumulation of soil organic matter. The organic matter accumulates an excessive $\mathrm{Cu}$ amount, which provides protection against too much copper being take up by the plants, the notion confirmed in the study by Mona et al. (2012) and Chennappa et al. (2017) who applied other nitrifying bacteria strains.

In the present work, increasing nitrogen fertiliser rates contributed to an increase in the spring wheat grain content of $\mathrm{Cu}$. Also research by Johansson et al. (2001), Buczek et al. (2011) and Jarecki et al. (2019) demonstrated that increasing nitrogen fertiliser rates produced an increase in copper content in cereal grain. However, the values were lower than WHO/FAO standards and thus posed no threat to human and animal health (2012). In the experiment reported here, an interaction was confirmed indicating the at the highest copper content was recorded in control spring wheat grain fertilised with $120 \mathrm{~kg} \mathrm{~N}^{\circ} \mathrm{ha}^{-1}$, it being the lowest following treatment with L-alpha proline + Azotobacter vinelandii without nitrogen fertiliser input.

\section{Conclusions}

1. The weather conditions significantly differentiated the content of micronutrients in the spring wheat grain. An application of biofertilizers increased iron and zinc contents, and reduced the concentration of manganese and copper in spring wheat grain.

2. Increasing nitrogen fertiliser rates, up to $90 \mathrm{~kg} \mathrm{~N}^{-1}$, contributed to an increase in the spring wheat grain content of the examined microelements.

3. The highest content of iron and zinc, and the lowest concentration of manganese and copper were recorded in spring wheat grain after application of L-alpha proline + Azotobacter vinelandii biological preparations with a dose of mineral nitrogen fertilization of $90 \mathrm{~kg} \mathrm{~N} \mathrm{ha}^{-1}$.

4. In conditions of sustainable agriculture, it is recommended to cultivate spring wheat with the use of the amino acid L-alpha proline with the bacteria Azotobacter vinelandii, at the level of mineral nitrogen fertilization with $90 \mathrm{~kg} \mathrm{~N} \mathrm{ha}^{-1}$, for broad agricultural practice.

5. Research should continue on the use of other strains of nitrogen bacteria and growth promoters in the cultivation of spring wheat.

\section{REFERENCES}

[1] Barczak, B., Klikocka, H., Kozera, W., Knapowski, T. (2018): Assessment of the effect of sulphur fertilization on oat grain yield and micronutrient uptake. - J. Elem. 23(1): 45-56. https://doi.org/10.5601/jelem.2017.22.1.1318.

[2] Buczek, J., Bobrecka-Jamro, D., Jarecki, W. (2011): Yield and quality of grain of selected spring wheat cultivars depending on the dose and the time of nitrogen application. - Frag. Agron. 28(4): 7-15.

[3] Calvo, P., Nelson, L., Kloepper, J. W. (2014): Agricultural uses of plant biostimulants. Plant Soil. 383: 3-41. https://doi.org/10.1007/s11104-014-2131-8.

[4] Chennappa, G., Naik, M. K., Amaresh, Y. S., Nagaraja, H., Sreenivasa, M. Y. (2017): Azotobacter: A Potential Biofertilizer and Bioinoculants for Sustainable Agriculture. - In: Panpatte, D., Jhala, Y., Vyas, R., Shelat, H. (eds.) Microorganisms for green revolution. Microorganism for Sustainability 6, Springer. 
[5] Colla, G., Rouphael, Y., Canaguier, R., Svecova, E., Cardarelli, M. (2014): Biostimulant action of a plant-derived protein hydrolysate produced through enzymatic hydrolysis. Front. Plant Sci. 5: 448. https://doi.org/10.3389/fpls.2014.0044.

[6] Delauney, A. J., Verma, D. P. S. (1993): Proline biosynthesis and osmoregulation in plants. - The Plant Journal 4: 215-223. https://doi.org/10.1046/j.1365-313X.1993.04020215.x.

[7] Du Jardin, P. (2015): Plant biostimulants: Definition, concept, main categories and regulation. - Sci. Hort. 196: 3-14. https://doi.org/10.1016/j.scienta.2015.09.021.

[8] Gondek, K., Gondek, A. (2010): The influence of mineral fertilization on the field and content of selected macro and microelements in spring wheat. - J. Res. Appl. Agric. Eng. 55(1): 30-36.

[9] Hill, T., Lewicki, P. (2006): Statistics: methods and applications. A comprehensive reference for science, industry and date mining. - StatSoft, ISBN 1-884233-59-7.

[10] Hoai, N. T. T., Shim, I. S., Kobayashi, K., Kenji, U. (2003): Accumulation of some nitrogen compounds in response to salt stress and their relationships with salt tolerance in rice (Oryza sativa L.) seedlings. - Plant Growth Regul. 41: 159-164.

[11] Jarecki, W., Buczek, J., Bobrecka-Jamro, D. (2019): Response of facultative cultivars of spring wheat to autumn sowing and foliar fertilization. - J. Elem. 24(2): 817-828. https://doi.org/10.5601/jelem.2018.23.4.1726.

[12] Johansson, E., Prieto-Linde, M. L., Jönsson, J. (2001): Effects of wheat cultivar and nitrogen application on storage protein compositioand bread-making quality. - Cereal Chem. 78(1): 19-25. https://doi.org/10.1094/CCHEM.2001.78.1.19.

[13] Luo, Y. W., Xie, W. H., Jin, X. X., Wang, Q., He, Y. J. (2013): Effects of germination on iron, zinc, calcium, manganese, and copper availability from cereals. - CyTa300 J. Food. 12(1): 22-26. https://doi.org/10.1080/19476337.2013.782071.

[14] Mahamed, H. H., Kaharia, M. (2012): Assessment of some heavy metals in vegetables, cereals and fruits in Saudi Arabian markets. - Egyp. J. Aqua. Res. 38: 31-37.

[15] Michalak, I., Chojnacka, K. (2013): Use of extract from Baltic seaweeds produced by chemical hydrolysis in plant cultivation. - Przem. Chem. 92: 1046-1049.

[16] Mona, E. E., Eman, R. H., Heba, S. S. (2012): Biofertilizers and/or some micronutrients role on wheat plants grown on newly reclaimed soil. - Afric. J. Ecol. 50: 464-475. https://doi.org/10.1111/j.1365-2028.2012.01342.x.

[17] Muhammad, I. R., Liyakat, H. M., Tanvir, S., Tatal, A., Iqbal, M. I., Mohammad, O. (2016): Bacteria and fungi can contribute to nutrients bioavailability and aggregate formation in degraded soils. - Microbiological Res. 183: 26-41. https://doi.org/10.1016/j.micres.2015.11.007.

[18] Qotob, M. A., Nasef, M. A., Elhakim, H. K. A., Shaker, O. G., Habashy, N. R., Abdelhamid, I. A. (2019): Integrated effect of plant growth regulators with boron sources on some biological parameters of sugar beet. - bioRxiv 839068; doi:https://doi.org/10.1101/839068.

[19] Radkowski, A., Radkowska, I. (2013): Effect of foliar application of growth biostimulant on quality and nutritive value of meadow sward. - Ecol. Chem. Eng. A. 20: 1205-1211. https://doi.org/10.2428/ecea.2013.20(10)110.

[20] Sharma, O. P., Bangar, S., Rajesh Jain, K. S., Sharma, P. K. (2004): Heavy metals accumulation in soil irrigated by municipal and industrial effluent. - J. Environ. Sci. Eng. 46(1): 65-73.

[21] Srinivas, N., Vinod Kumar, B., Suresh Kumar, K. (2002): Lead Pollution in Roadside Plant in Visakhapatnam. - J Envir. Stud. Pol. 5(1): 63-68.

[22] Sułek, A., Cacak-Pietrzak, G. (2008): Formation the quality characteristics of spring wheat varieties depending on nitrogen fertilization. - Frag. Agron. 25(1): 400-409.

[23] Szmigiel, A., Oleksy, A., Kołodziejczyk, M. (2014): Effect of nitro gen fertilization on quality and quantity in spring wheat. - EJPAU 17(2): 1.

[24] Wang, Z., Li, S., Malhi, S. (2008): Effects of fertilization and other agronomic measures on nutritional quality of crops. - J. Sci. Food Agric. 88: 7-23. 